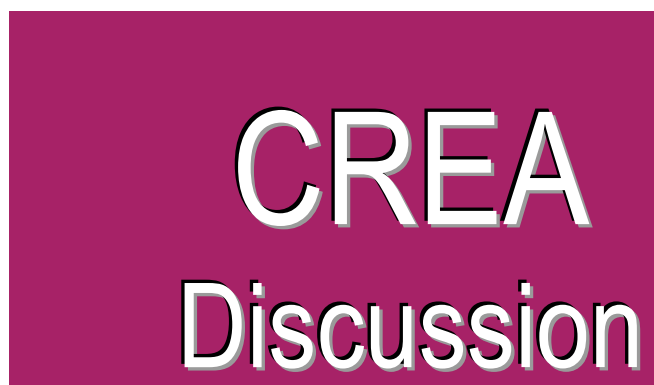
Paper 2019-07 Economics

\title{
Do potential migrants internalise migrant rights in OECD host societies?
}

available online : http://wwwfr.uni.lu/recherche/fdef/crea/publications/discussion_papers

Michel Beine, CREA, University of Luxembourg, L Joël Machado, Luxembourg Institute of Socio-Economic Research (LISER), L Ilse Ruyssen, CESSMIR, Ghent University and Université catholique de Louvain, B

May, 2019

For editorial correspondence, please contact: crea@uni.lu University of Luxembourg Faculty of Law, Economics and Finance 162A, avenue de la Faïencerie L-1511 Luxembourg 


\title{
Do potential migrants internalise migrant rights in OECD host societies?
}

\author{
Michel Beine $^{\mathrm{a}}$, Joël Machado ${ }^{\mathrm{b}}$, and Ilse Ruyssen ${ }^{\mathrm{c}}$ \\ ${ }^{a}$ CREA, University of Luxemburg* \\ ${ }^{\mathrm{b}}$ Luxembourg Institute of Socio-Economic Research (LISER) ${ }^{\dagger}$ \\ ${ }^{\mathrm{c}}$ CESSMIR, Ghent University ${ }^{\ddagger}$ and IRES, Université catholique de Louvain
}

\begin{abstract}
This paper analyses how countries' provision of migrant rights affects potential migrants' destination choice. Combining data on bilateral migration desires from over 140 origin countries and data on policies in 38 destination countries over the period 2007-2014, we find that potential migrants tend to favour destinations that are more open to the inclusion of immigrants into their society. In particular, better access to and conditions on the labour market, as well as access to nationality and to permanent residency significantly increase the perceived attractiveness of a destination country. These results hold for subsamples of origin countries as well as of destinations and are robust to a set of methodological concerns, including endogeneity. Moreover, results of some policies vary across types of respondents. Educational opportunities for migrants, for instance, affect the migration desires of individuals aged 15 to 24 years, but not of individuals in other age groups.
\end{abstract}

Keywords: Migration desires, Migrants' destination choice, Migrant rights, Quality of institutions

*Address: CREA, 162a, avenue de la Faïencerie, L-1511 Luxembourg; Email: michel.beine@uni.lu

${ }^{\dagger}$ Address: Maison des Sciences Humaines, 11, Porte des Sciences, L-4366 Esch-sur-Alzette/Belval, Luxembourg; Email: joel.machado@liser.lu (corresponding author)

${ }_{\ddagger}^{\ddagger}$ Address: Department of Economics, Ghent University, Tweekerkenstraat 2, B-9000 Gent, Belgium; Email: ilse.ruyssen@ugent.be 
JEL codes: F22, O15, P16, 057

\section{Introduction}

Immigration has shaped the debates during many recent elections, including the Brexit campaign, the 2017 presidential elections in the United States and national elections in Austria, France, Germany and Italy (among others). In order to design effective policies regulating immigration flows, understanding the determinants of prospective immigrants' decision is key. Particularly relevant in this regard is the impact of different types of policies on the attractiveness of destination countries and the ensuing migration flows. The objective of this paper is to provide a better understanding of how institutional policies regulating immigrants' integration and rights influence migrants' destination choice.

An important literature focuses on the possible determinants of international migration, both on the actual flows and on the desired movements of people, relying on theory-based pseudo-gravity models (for a survey, see Beine et al., 2016). This literature discusses the role of several key factors such as expected relative incomes (see e.g. Docquier et al., 2014, Grogger and Hanson, 2011) as well as non-economic and historical determinants such as geographical distance, colonial ties and cultural proximity. Moreover, the presence of large networks at destination have been shown to facilitate the movement of new immigrants from the same origin country, both in terms of actual flows (Beine et al. 2011) and desired moves (Bertoli and Ruyssen, 2018). Furthermore, migratory flows are influenced by push factors like climate change, natural disasters and conflicts in countries of origin (Beine and Parsons, 2015; Cattaneo and Peri, 2016). Finally, conditions of access/entry to destination countries regulating the observed migration flows are found to be important determinants: Bertoli and Moraga (2013) look at the role of bilateral immigration policies and show that the introduction of a travel visa requirement reduces direct bilateral flows by 40 to 47 percent 1

The role of the institutional setting at origin and destination in shaping migration flows has so far been addressed in rather general terms (see Baudassé et al., 2018 for a recent review of the link between immigration and institutions). Existing studies focus on the

\footnotetext{
${ }^{1}$ For a comprehensive overview of the literature on the economics of international migration and the effectiveness of immigration policies in shaping migration patterns in particular, see Hatton (2014).
} 
impact of broad institutional indicators such as economic freedom (Ashby, 2010; Nejad and Young, 2016), the quality of governance (Ariu et al., 2016, Bergh et al., 2015) and the generosity of the welfare system (De Giorgi and Pellizzari, 2009, Pedersen et al., 2008) on observed migration flows. Moreover, labour market institutions such as employment protection (Bazillier and Moullan, 2012; Geis et al., 2013), trade union density and power (Cigagna and Sulis, 2015, Migali, 2018) and minimum wages (Cigagna and Sulis, 2015, Giulietti, 2014) have been considered as potential determinants of location choice.

Surprisingly, the impact of the institutional setup shaping immigrants' integration and rights has received rather limited attention. The current paper aims to fill this gap in the literature by combining a unique micro level dataset on stated emigration desires in 145 countries worldwide, provided by the Gallup World Poll (GWP) survey, with various subindicators of the Migrant Integration Policy Index (MIPEX). These indicators, available between 2007 and 2014, cover a wide range of policies and rights explicitly pertaining to the integration of immigrants. The granularity provided by these indicators is an advantage compared to more general measures describing the institutional framework or governance indicators affecting the overall population. Specifically, MIPEX provides information on the rights entitled to migrants in the following integration dimensions: labour market access and mobility, permanent residence, naturalisation, family reunification, political participation and education. It is available for up to 38 countries, including a large set of the main destination countries for worldwide migration.

The literature on migration desires is small but growing (Becerra, 2012; Carling, 2002; Creighton, 2013; Drinkwater and Ingram, 2009; Dustmann and Okatenko, 2014; Jonsson, 2008; van Dalen et al., 2005a,b) and characterized by an ongoing discussion on whether migration desires actually signal a person's migration plans as opposed to pure wishful thinking (Manchin et al., 2014; van Dalen and Henkens, 2008). The intentions to migrate that we define in this paper are, however, stricter than mere migration considerations as used by e.g. Creighton (2013). Whereas the latter considers whether the respondent has thought about moving outside the locality or community where he or she lives in the future, the GWP use a stronger formulation which directly asks for the likely response under ideal conditions (Manchin et al., 2014). Hence, analysing the effect of institutional settings, besides traditional determinants of migration such as economic prospects, distance, networks and common historical links, on emigration desires rather than on observed flows yields several specific 
insights. First, any actual migration movement of individuals is based on expectations and desires. As such, an analysis of what drives the migration desire in itself may significantly contribute to our understanding of global migration patterns. In that respect, Bertoli and Ruyssen (2018) show that there is a strong correlation between desired migration choices and actual flows. Second, the choice set of potential desired destinations is unconstrained: a respondent desiring to move abroad can state any country as preferred destination without limitation, even if he does not have the means to actually move. Third, observed migratory movements are strongly affected by restrictions induced by immigration policies. While a respondent may be willing and able to afford to move to his or her desired destination, he or she might not be allowed to do so for legal reasons. In other words, the use of desired migration flows allows to neutralise the role of out-selection factors such as immigration policies and to better identify the effect of self-selection factors such as migrant entitlements and rights at destination. Finally, the data on migration desires provide a direct estimate of the number of aspiring stayers, i.e. people choosing to stay in their country as their optimal choice. This number is often cumbersome to compute in data on actual moves.

To empirically analyse the choice of desiring migrants among the 38 alternative destinations, we compute the bilateral share of desiring migrants and estimate a gravity model using the Pseudo Poisson Maximum Likelihood estimator (PPML) to account for the high occurrence of zeros in our dependent variable. The model includes origin-year fixed effects (FE) capturing all the origin-specific factors as well as destination FE capturing time-invariant factors that are specific to a destination. Our evidence indicates that immigrants tend to favour countries with more generous regulations specific to them in terms of labour market access, access to permanent residence as well as easier access to the nationality of the host country. These results are robust across different specifications. The positive and highly significant coefficient is preserved when altering the choice set by dropping the United States or the new member states of the European Union. The results remain valid when we keep in the sample only origin countries for which the main destination is also available in MIPEX or when we focus only on countries for which data is available throughout the entire period 2007-2014.

Furthermore, our estimation approach is exposed to the usual threats to identification. The first is posed by potential reverse causality stemming from the fact that laws and institutions are likely to react to (past or expected) migration flows. In order to address 
this potential source of endogeneity, we provide instrumental variable (IV) estimates using the age structure of the population in the destination country as an instrument. Second, to mitigate the concern that our variables of interest are subject to measurement error, we run a placebo test, re-estimating our benchmark model on the subsample of Schengen countries as well as various other subsets of destinations. Third, we run our estimations using a more demanding dyadic fixed effects structure in order to address potential omitted variable bias. These different robustness checks confirm our benchmark results.

Interestingly, the Gallup data allow to account for a heterogeneous impact of the various MIPEX indicators on migration desires by re-estimating our benchmark model on different subsamples of respondents, i.e. for low versus high skilled, men versus women, working age versus young, respondents with or without children and respondents with or without a partner. We find that labour market mobility seems to be slightly more important for men than for women, although it remains the most significant and important indicator for the latter. Access to education opportunities are particularly important for individuals aged 15 to 24 , who might benefit from educational opportunities at destination.

The paper is organised as follows. Section 2 provides a brief literature review. Section 3 presents our key data while section 4 discusses the econometric specification and the measurement of key variables used in the empirical analysis. Section 5 presents the benchmark results as well as the results of a number of robustness tests and those obtained from allowing for a heterogeneous response of policies across categories of respondents. Section 6 concludes.

\section{Literature Review}

Most of the existing literature has focused on the general institutional setting of the origin and destination countries, affecting both migrants and non-migrants. Ashby (2010), for instance, finds a positive impact of the economic freedom differential between the origin and destination country on migration flows whereas the effect of political freedom is less robust. Nejad and Young (2016) show that it is the economic freedom in destination countries that acts as a pull factor for migrants. Using six governance indicators based on the Worldwide Governance Indicators (Kaufmann et al. 2009), Ariu et al. (2016) find that net inflows of high skilled emigration are driven by the quality of governance in both the origin and 
destination countries. For low-skilled individuals however, they do not find a significant effect of institutions in the destination countries. Similarly, Bergh et al. (2015) use an updated version of the Worldwide Governance Indicators to proxy political and economic institutions which include government effectiveness, control of corruption, regulatory quality, rule of law, political stability, and voice and accountability. Institutional quality is found to be an important push factor at origin whereas institutions at destination play a limited role: only effective bureaucracy and control of corruption affect immigration.

The role of labour market institutions has also received some attention. Using microdata, Geis et al. (2013) find that employment protection in France, Germany, the United Kingdom, and the United States has a positive impact on immigration and the decision of immigrants to stay. Migali (2018) finds that a higher trade union density is associated with lower Intra-EU migration whereas unemployment protection legislation has no clear effect. Bazillier and Moullan (2010) and Bazillier and Moullan (2012) show that a high employment protection differential between the origin and destination countries is associated with low migration flows. Giulietti (2014) exploits the between-states variation in minimum wages in the United States in 1996-1997 and 2007-2009 to study its impact on immigration. He shows that a higher minimum wage tends to attract low-skilled workers but does not affect the inflows of illegal and high skilled immigrants. Cigagna and Sulis (2015) analyse the effect of unemployment and labour institutions such as employment protection legislation, coverage of unemployment benefits, minimum wages, union power and tax wedge on migration flows for a sample of 15 OECD countries over the period 1980-2006. The authors find strong and negative effects of unemployment, employment protection and migration policy on flows and positive effects for minimum wages, unemployment benefits and union power.

A few studies have so far relied on the Gallup World Polls to investigate the patterns and determinants of migration intentions, without using the information about the preferred destination (see e.g. Dustmann and Okatenko, 2014; Esipova et al., 2011; Manchin and Orazbayev, 2018). Alternatively, Docquier et al. (2015), Docquier and Machado (2016) and Delogu et al. (2018) have used the origin-specific proportion of the individuals who intend to move to each foreign destination in their analyses of the short- and long-run efficiency gains of a removal of the legal restrictions to migration, assuming that the answers to the hypothetical questions in the Gallup World Polls are informative about the scale of liberalised migration flows. 
Other papers have focused on the dyadic dimension of the Gallup data to shed light on some interesting patters of international migration. Docquier et al. (2014) empirically analyse the country-specific and dyadic factors governing the size and the composition of the bilateral pool of intending migrants, as well as the probability that these intentions are realised. Dao et al. (2018) also make use of the origin-specific shares of individuals aspiring to migrate abroad as well as realisation rates by education level to disentangle the effects of both microeconomic and macroeconomic drivers of the migration transition curve, i.e. the inverted- $U$ shaped relationship between emigration rates and economic development. Bertoli and Ruyssen (2018) empirically investigate to what extent the destination choice of aspiring migrants is influenced by the presence of distance-one connections in potential destination countries. Separate conditional logit regressions for each of the 147 countries of origin reveal that distance-one connections can alter the ranking of most pairs of destinations. Ruyssen and Salomone (2018) track both women's migration desires as well as preparations they have already made to migrate within the next 12 months and disentangle how gender discrimination fosters or impedes female migration across countries. Gubert and Senne (2016) consider information on individuals' plans to move within the next 12 months to explore the relative attractiveness of EU-countries as potential destinations. None of these studies, however, explicitly controls for institutions at destination. Our paper adds to this particular strand of the literature by explicitly linking migration desires with migrant rights at destination.

\section{Data}

In order to analyse the impact of migrant rights on the attractiveness of destination countries, we combine data on migration desires from the Gallup World Polls with data from the Migrant Integration Policy Index.

\subsection{Migration desires - Gallup World Polls}

Gallup conducts surveys in more than 160 countries (including 99 per cent of the world's population aged 15 and over). In each country, at least 1000 individuals are surveyed by phone and face-to-face interviews (Gallup, 2018). The sample of individuals interviewed is representative of the resident population older than 15 years. Gallup World Poll survey 
data is probably the most comprehensive source of data on migration desires. Two relevant questions on migration desires are asked. The first question is: "Ideally, if you had the opportunity, would you like to move permanently to another country, or would you prefer to continue living in this country?". If respondents reply positively, a follow-up question asks about the desired destination country: "To which country would you like to move?".

An appealing feature of the data is that it provides a large set of personal characteristics of the respondents such as gender, age, family structure and education. Although the data is cross-sectional, its annual structure between 2007 and 2015 allows to account for the time variation in migration desires. On average, around $20 \%$ of respondents express a desire to migrate (see Docquier et al., 2014, for an early description of the Gallup data). Interestingly, preferred migration destinations are more concentrated than observed bilateral flows. Destinations for which MIPEX data is also available account for $74 \%$ of the total desired destinations. Table 1 summarises, for the top 10, top 20 and top 30 destinations, the number of times a country within the group is mentioned by respondents. The number of countries within the group for which MIPEX data is available is also provided. Moreover, Table 1 ] shows the relative importance of these destinations among total responses in the form of the share of these destinations among all the countries mentioned. More precisely, the top 10 destinations account for $67 \%$ of all migration desires and are mentioned more than 162,000 times by respondents. The ranking of the destinations for which MIPEX data is available (and that hence can be included in our sample) is provided in Table A.1.

Table 1: Concentration of destinations

\begin{tabular}{lccc}
\hline \multicolumn{4}{c}{ Summary statistics GWP and MIPEX } \\
\hline Sample of GWP dest. & \# Mention in GWP & in MIPEX & Share dest. \\
\hline Top 10 & 162,406 & 8 & $67 \%$ \\
Top 20 & 195,282 & 13 & $81 \%$ \\
Top 30 & 209,503 & 19 & $87 \%$ \\
in MIPEX & 179,852 & 38 & $74 \%$ \\
\hline
\end{tabular}

Notes: The table shows for each sample of destinations appearing in the Gallup World Polls (and MIPEX in the final row) the number of respondents in the GWP mentioning one of these countries as their preferred destination (column 2), how many of these countries also appear in the MIPEX database (column 3), and the share of respondents reported in column 2 mentioning one of the countries in this set as preferred destination (column 4). 
Note that $63 \%$ of possible bilateral desired flows are zeroes. Relying on Poisson PseudoMaximum Likelihood (PPML) estimators, as is now standard in the literature (see Beine et al., 2016), allows to account for the potential issues arising from the high proportion of zeroes in the dependent variable (Santos Silva and Tenreyro, 2006).

\subsection{MIPEX}

The Migrant Integration Policy Index (MIPEX) provides various measures of rights entitled to migrants in different integration areas in all EU25 Member States, Canada, Norway and Switzerland between 2007 and 2014는 Indicators for Australia, Bulgaria, Japan, South Korea, New Zealand, Romania, Turkey and the USA are available as of 2010. Finally, Croatia is covered from 2012 and Iceland from 2013 onwards. As discussed previously, the 38 MIPEX countries account on average for about $74 \%$ of desired destinations $3^{3}$ However, for some important desired destination countries such as Saudi Arabia, South Africa and Russia, MIPEX is unavailable (see Table A.2 for a list of the main destinations in the Gallup World Poll data for which MIPEX is unavailable). Our results must thus be interpreted in light of the sample composition of the countries for which we have data, that nevertheless represent a large majority of the stated desired destinations.

MIPEX includes 167 policy indicators that measure migrant rights in a multidimensional way. We use 6 broad policy areas of interest, including 'Labour Market Mobility' (i.e. immigrants' access to jobs and job training as well as labour market conditions), 'Family Reunion' (i.e. who is eligible to bring family members, which family members can be sponsored, and under what conditions), 'Education' (i.e. access to education for immigrant youth as well as opportunities for intercultural education), 'Political Participation' (i.e. electoral rights, political liberties and the presence of immigrant consultative bodies), 'Permanent Residence' (i.e. eligibility criteria and possibility of revocation), and 'Access to Nationality' (i.e. eligibility criteria and possibility of dual citizenship) 4 It is worth noting that these indicators do not capture immigration legislation per se, i.e. the conditions for legal entry in a specific country. They rather define the living and working conditions that immigrants can expect

\footnotetext{
${ }^{2}$ The data is available at http://http://www.mipex.eu retrieved in January 2018.

${ }^{3}$ This figure ranges between $71 \%$ in 2014 and $77 \%$ in 2007 . These yearly differences are at least partially explained by the sample composition: over time, additional countries which had a lower propensity to mention a preferred destination that is part of the MIPEX sample were added to the Gallup survey.

${ }^{4}$ Note that the Education indicator is only available as of 2010.
} 
to have access to, conditional on living in the country. This also justifies why we reason in terms of "migrant rights" rather than "integration policies": we do not analyse the impact of specific policies implemented but rather that of the general framework of living conditions provided to immigrants. Each policy area is divided into sub-categories, each one containing several questions (sub-indicators) related to a specific right for immigrants in the host country. The sub-indicator takes the values 0,50 or 100 where the highest value translates into the full right, a value of 50 stands for conditional or partial application, whereas 0 reflects the absence of that right. The higher the value of the indicator, the easier the access immigrants have to a specific right. Some examples of sub-indicators are provided in Table 2 .

Table 2: MIPEX: Examples of Questions

\begin{tabular}{|c|c|c|c|c|}
\hline \multirow[t]{2}{*}{ Policy area } & \multirow[t]{2}{*}{ Sub-indicator } & \multicolumn{3}{|c|}{ Potential sub-indicator values } \\
\hline & & 100 & 50 & 0 \\
\hline $\begin{array}{l}\text { Labour Market } \\
\text { Mobility }\end{array}$ & $\begin{array}{l}\text { Immediate access to labour market: } \\
\text { What categories of foreign residents have } \\
\text { equal access to employment as nationals? } \\
\text { A. Permanent residents } \\
\text { B. Residents on temporary work permits } \\
\text { (excl. seasonal) within period of } 1 \text { year } \\
\text { C. Residents on family reunion permits }\end{array}$ & All of them & $\begin{array}{l}\mathrm{A} \text { and }[\mathrm{C} \text { or } \\
\text { certain categ. of } \mathrm{B}]\end{array}$ & Only A or None \\
\hline $\begin{array}{l}\text { Family Reunion for } \\
\text { Foreign Citizens }\end{array}$ & $\begin{array}{l}\text { Residence requirement for } \\
\text { ordinary legal residents (sponsor) }\end{array}$ & No residence requirement & 1 year & $>1$ year \\
\hline Permanent Residence & $\begin{array}{l}\text { Eligibility: Required time } \\
\text { of habitual residence }\end{array}$ & $<5$ years & 5 years & $>5$ years \\
\hline
\end{tabular}

Notes: The table presents examples of sub-indicators for various policy areas covered by MIPEX, along with the potential values these sub-indicators can take.

\subsection{Additional Controls}

Our estimations account for the traditional determinants of migration flows discussed in the existing literature (see e.g. Beine et al., 2016). The difference between GDP per capita at origin and at destination is used as a proxy for migrants' prospects of improving their economic situation. Yearly data on GDP per capita (in PPP, constant 2011 international \$) is taken from the World Development Indicators (WDI). Destination country size is proxied by the size of the destination population for which yearly data is provided by the WDI. Cultural and historical links are proxied by dyadic dummy variables for a common official 
language, shared colonial history and a measure of geodesic distance taken from CEPII (see Mayer and Zignago, 2011). The diaspora size is proxied by the migrant stock of the same origin in the year 2001, taken from the OECD DIOC-E database.

\section{The model}

In order to analyze the impact of migrant rights on migration desires, we estimate the following model:

$$
\begin{aligned}
\ln \left(\frac{M_{i j t}}{M_{i i t}}\right) & =\alpha+\gamma_{i t}+\gamma_{j}+\beta_{1} \ln \left(\text { MIPEX }_{j t-1}\right)+\beta_{2} \ln \left(\text { PoP }_{j t}\right) \\
& +\beta_{3} \ln \left(\text { GDPpcdiff } f_{i j t}\right)+\beta_{4} \ln \left(\text { Netw }_{i j 2001}\right)+\sum_{z} \beta_{z} \text { controls }_{i j}+\epsilon_{i j t},
\end{aligned}
$$

where $i$ and $j$ denote the country of origin and destination respectively. The dependent variable, $\ln \left(M_{i j t} / M_{i i t}\right)$, is the log-ratio of individuals with permanent migration desires from

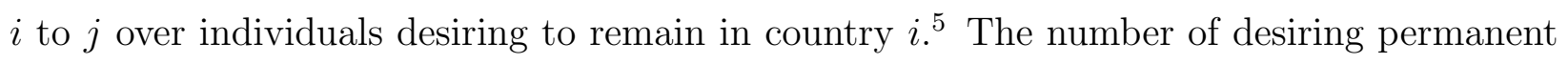
migrants is adjusted as follows in order to correct for the absence of a valid destination among some respondents:

$$
M_{i j t}=\text { Desire }_{i j t} / \sum_{j \neq i} \text { Desire }_{i j t} * Y e s_{i t} / \text { TotRespondents } s_{i t} .
$$

The first term of the right-hand side provides the share of individuals who want to move from

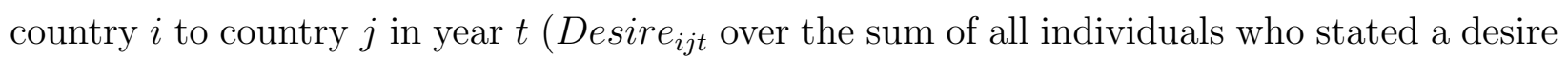
to emigrate and a destination, $\sum_{j \neq i}$ Desire $\left._{i j t}\right)$. This first term is multiplied by the ratio of individuals who have replied positively to the question on migration desires (Yesit) over the total number of respondents to the same question (TotRespondents $s_{i t}$ ). This adjustment allows to account for the desire to emigrate of some individuals who replied positively to the question on migration desire but did not provide a (valid) destination. Specifically, this concerns the following cases: the respondent did not provide any destination (while expressing a desire to leave), the respondent mentioned an unspecified group, such as "other

\footnotetext{
${ }^{5}$ This equation is micro-founded following the commonly used Random Utility Model from which the dependent variable, the ratio $\ln \left(\frac{M_{i j t}}{M_{i i t}}\right)$, is directly derived (see for instance Beine et al. 2016). An appealing feature of the Gallup data is that they provide a direct estimate of $M_{i i t}$, while with data on actual moves, it often has to be estimated.
} 
country" or "island state", instead of an existing country. The number of stayers (i.e. individuals who do not express a desire to emigrate) is given by

$$
M_{i i t}=N_{o_{i t}} / \text { TotRespondents } s_{i t}
$$

and is expressed as the share of respondents who do not desire to emigrate. Note that, as both the numerator and the denominator of equation (1) account for the number of respondents in country $i$ at time $t$, the standard formula used in the literature would be recovered if all individuals who express a desire to emigrate would have also provided a destination (i.e. $\sum_{j \neq i}$ Desire $\left._{i j t}=Y e s_{i t}\right)$. The specification includes origin-time FE, $\gamma_{i t}$, and destination FE, $\gamma_{j}$. Our main variable of interest, the (one-year) lagged MIPEX indicator $\left(M I P E X_{j t-1}\right)$, alternatively reflects the 6 broad policy areas described above: Labour Market Mobility (LabMobl), Family Reunion (FamReunl), Permanent Residence (PermResidl), Access to Nationality (Nationl), Political Participation (Polpartl), and Education (Educl) $!^{6}$ As additional controls, we also account for other time-varying destination characteristics, such as population at destination, as well as bilateral variables such as the log-ratio of GDP per capita, networks and controls for geographic and cultural proximity. Equation (1) is estimated using Poisson Pseudo-Maximum Likelihood (PPML) estimators, which allow to account for the large amount of zero flows.

\section{Results}

\subsection{Benchmark results}

If prospective migrants are fully rational and internalise migrant rights at destination, we expect that more generous institutional frameworks make countries more attractive, and hence the main coefficient of interest, $\beta_{1}$, is expected to be positive.

Table 3 reports the benchmark results. Focusing on the estimate of $\beta_{1}$, i.e. the estimated impact of a category of migrant rights, we find that two categories in particular affect the

\footnotetext{
${ }^{6}$ In our baseline specification, we lag the indicator by one year in order to make sure that a migration desire was not expressed before a change in the migrant's right in the same year. The impossibility to know exactly at which moment a given migrant right evolves within the year leads us to assume that the indicator value is valid throughout the whole year. Hence, we assume that the desire to emigrate is based on the indicator value at the end of the previous year. A robustness check using contemporaneous indicators and migration desires presented in Table B.3 shows that results are qualitatively unaffected.
} 
migration desires. Access to the labour market for migrants and possibilities of acquiring the nationality of the destination country tend to increase the attractiveness of the destination for aspiring migrants. Moreover, the easiness of getting Permanent Residence is found to have a positive impact, albeit in a less significant way. Immigrants' access to the labour market tends to exert the highest impact, confirming the importance of economic prospects for potential migrants. Given that the Gallup survey involves questions about a permanent move, it makes sense that prospects of getting permanent residence and the nationality play a role in the way migrants form their optimal choice of location.

Table 3 shows that all the remaining coefficients exhibit the expected sign. Migration desires between two countries significantly increase with the difference in GDP per capita, with a shared official language, a common colonial history and the size of the existing national diaspora at the destination. Geographic distance decreases migration desires between two countries, as does membership of the Schengen area. The latter can probably be explained by the fact that individuals within the Schengen area have a rather easy access to countries within the free-mobility zone and thus can easily realise their desire. Interestingly, the six different MIPEX indicators are associated with a positive coefficient (i.e. $\beta_{1}>0$ ). Higher Labour Market Mobility, Access to Nationality and Permanent Residence are associated with significantly higher migration desires from country $i$ to country $j$ at time $t$. 
Table 3: Benchmark estimations

\begin{tabular}{|c|c|c|c|c|c|c|}
\hline & M1 & M2 & M3 & M4 & M5 & M6 \\
\hline $\operatorname{lnGDPpcdiff}$ & $\begin{array}{c}3.193^{* * *} \\
(7.01)\end{array}$ & $\begin{array}{c}3.321^{* * *} \\
(7.34)\end{array}$ & $\begin{array}{c}3.286^{* * *} \\
(7.17)\end{array}$ & $\begin{array}{c}3.502^{* * *} \\
(6.82)\end{array}$ & $\begin{array}{c}3.273^{* * *} \\
(7.12)\end{array}$ & $\begin{array}{c}3.616^{* * *} \\
(5.46)\end{array}$ \\
\hline $\operatorname{lnPopD}$ & $\begin{array}{l}1.103 \\
(0.88)\end{array}$ & $\begin{array}{l}0.292 \\
(0.23)\end{array}$ & $\begin{array}{l}0.319 \\
(0.25)\end{array}$ & $\begin{array}{l}1.027 \\
(0.81)\end{array}$ & $\begin{array}{l}0.165 \\
(0.13)\end{array}$ & $\begin{array}{l}0.916 \\
(0.47)\end{array}$ \\
\hline lndistw & $\begin{array}{c}-0.577^{* * *} \\
(-9.07)\end{array}$ & $\begin{array}{c}-0.580^{* * *} \\
(-9.12)\end{array}$ & $\begin{array}{c}-0.579^{* * *} \\
(-9.08)\end{array}$ & $\begin{array}{c}-0.579^{* * *} \\
(-9.12)\end{array}$ & $\begin{array}{c}-0.580^{* * *} \\
(-9.12)\end{array}$ & $\begin{array}{c}-0.579^{* * *} \\
(-9.21)\end{array}$ \\
\hline commlangoff & $\begin{array}{c}0.883^{* * *} \\
(9.15)\end{array}$ & $\begin{array}{c}0.886^{* * *} \\
(9.11)\end{array}$ & $\begin{array}{c}0.884^{* * *} \\
(9.10)\end{array}$ & $\begin{array}{c}0.886^{* * *} \\
(9.15)\end{array}$ & $\begin{array}{c}0.887^{* * *} \\
(9.15)\end{array}$ & $\begin{array}{c}0.856^{* * *} \\
(9.48)\end{array}$ \\
\hline Schengenij2010 & $\begin{array}{c}-0.244^{* *} \\
(-1.97)\end{array}$ & $\begin{array}{c}-0.250^{* *} \\
(-2.02)\end{array}$ & $\begin{array}{c}-0.245^{* *} \\
(-1.98)\end{array}$ & $\begin{array}{c}-0.248^{* *} \\
(-2.00)\end{array}$ & $\begin{array}{c}-0.251^{* *} \\
(-2.03)\end{array}$ & $\begin{array}{l}-0.186 \\
(-1.48)\end{array}$ \\
\hline colony & $\begin{array}{c}0.494^{* * *} \\
(4.14)\end{array}$ & $\begin{array}{c}0.495^{* * *} \\
(4.14)\end{array}$ & $\begin{array}{c}0.494^{* * *} \\
(4.13)\end{array}$ & $\begin{array}{c}0.494^{* * *} \\
(4.13)\end{array}$ & $\begin{array}{c}0.495^{* * *} \\
(4.15)\end{array}$ & $\begin{array}{c}0.498^{* * *} \\
(4.65)\end{array}$ \\
\hline $\operatorname{lnLij} 2001$ & $\begin{array}{c}0.172^{* * *} \\
(10.16)\end{array}$ & $\begin{array}{c}0.172^{* * *} \\
(10.14)\end{array}$ & $\begin{array}{c}0.172^{* * *} \\
(10.16)\end{array}$ & $\begin{array}{c}0.172^{* * *} \\
(10.17)\end{array}$ & $\begin{array}{c}0.172^{* * *} \\
(10.15)\end{array}$ & $\begin{array}{c}0.172^{* * *} \\
(10.25)\end{array}$ \\
\hline lnLabMobl & $\begin{array}{c}1.279^{* * *} \\
(4.75)\end{array}$ & & & & & \\
\hline lnFamReunl & & $\begin{array}{l}0.167 \\
(0.72)\end{array}$ & & & & \\
\hline lnPermResidl & & & $\begin{array}{l}0.736^{*} \\
(1.78)\end{array}$ & & & \\
\hline lnNationl & & & & $\begin{array}{c}0.695^{* * *} \\
(5.70)\end{array}$ & & \\
\hline lnPolPartl & & & & & $\begin{array}{l}0.045 \\
(0.37)\end{array}$ & \\
\hline $\operatorname{lnEducl}$ & & & & & & $\begin{array}{l}0.399 \\
(1.19)\end{array}$ \\
\hline Observations & 26493 & 26493 & 26493 & 26493 & 26493 & 20118 \\
\hline Orig-time FE & YES & YES & YES & YES & YES & YES \\
\hline Dest. FE & YES & YES & YES & YES & YES & YES \\
\hline
\end{tabular}

Notes: $t$ statistics in brackets; ${ }^{* * *},{ }^{* *},{ }^{*}$ denote significance at the 1,5 and $10 \%$ level, respectively. Standard errors are clustered by countries of origin.

\subsection{Robustness}

In this section, we check the robustness of our results to different specifications, thereby addressing several endogeneity concerns stemming from potential reverse causality and measurement error. Section 5.2.1 deals with potential endogeneity bias related to reverse causality using an IV approach. In section 5.2.2, we provide a Placebo test on the subsample of within-Schengen area bilateral corridors, where aspiring migrants have similar rights as 
native citizens. In section 5.2.3, we change the sample of countries considered.

\subsubsection{IV approach}

Our benchmark estimations support a positive impact of some categories of migrant rights on the attractiveness of the destinations for aspiring migrants. Nevertheless, these estimations are subject to some endogeneity concerns due to a potential feedback effect of past or future attractiveness on countries' devotion to immigrant integration in the host society. For instance, if a country tends to be highly attractive (as measured by a high proportion of migrants wishing to migrate to this country), it might prefer to design policies protecting the native workers, resulting in a relatively more difficult access for migrants to the domestic labour market. If this is the case, our PPML estimates of the impact of the MIPEX indicators $\left(\beta_{1}\right)$ might be biased. Note that the direction of the bias depends on the specific direction of the feedback effect. In the previous example, to the extent that this feedback effect exists in this particular form, $\beta_{1}$ will be underestimated in absolute terms. The sign and amplitude of these potential biases for $\beta_{1}$ are also likely to depend on the specific categories of migrant rights.

Nevertheless, endogeneity issues associated to reverse causality are mitigated by the use of a dyadic framework to the extent that it is difficult to imagine how the increase of perceived attractiveness in one specific origin country could induce the government to alter its overall policy stance towards the integration of migrants. Of course, in the specific case of a high concentration of immigrants from a given origin (such as the Mexicans in the United States or the Turks in Germany), this cannot completely be ruled out. However, even in that case, the feedback effects would be driven by a few observations. Note also that in model (1), we use one-year lagged MIPEX indicators, which rules out contemporaneous feedback effects from attractiveness to migrant rights.

In order to deal with endogeneity concerns, we follow an instrumental variable approach and reestimate equation (1) instrumenting the migrant rights indicator. We focus on the rights regarding the integration of immigrants in the labour market since this is the integration area with the strongest impact in the benchmark estimations. We use the age structure of the population in the destination country as an instrument for the entitlements determining immigrants' access to the labour market. Our IV variable is defined as the share of the population at working age. The correlation between the age structure and the rights 
entitled to migrants is likely to be context-specific and is difficult to know ex-ante. For instance, in destination countries with pay-as-you-go pension schemes, the dependency ratio and the share of the working population play a crucial role for the sustainability of public finances. This should be reflected in a facilitation of the labour market access of migrants in host countries to foster their fiscal contributions, implying a negative relationship between the share of the working-age population and labour market access requirements. A similar relationship can be expected in countries where the unemployment rate for native workers is high. In this case, in order to protect native workers from increased labour market competition, authorities may restrict the rights entitled to migrants in order to slow down immigrant integration. Also cultural arguments might play aside from these economic arguments. In countries with an ageing population, people might be in general more conservative and reluctant to a mixed society, such that policies limiting the rights entitled to migrants receive more support, which would suggest a positive relationship between the size of the working age population and immigrants' access to the labour market. Therefore, the sign of the first stage correlation remains an empirical question. The assumption behind the exclusion restriction is that in forming their expectation about future locations, aspiring migrants do not internalise the age structure of potential destinations.

The use of instrumental variables in exponential models such as PPML (PPML IV hereafter) is complicated by the inclusion of the FE. While several estimators have been developed within the GMM framework (Windmeijer and Santos Silva, 1997), one of the issues is the failure of convergence in the presence of a rich structure of $\mathrm{FE}$ like the one used in our benchmark estimations. PPML IV tends to work well with one or two dimensions of FE (see Tenreyro, 2007), but is difficult to use when accounting for origin-time FE as well as destination FE as we do in our estimations. The use of a two-step estimator is an empirical solution but remains nevertheless inconsistent (see Cameron and Trivedi, 2013). Another concern is the incidental parameter problem when more than one FE is included in a PPML IV setting:7 Consequently, we favour the use of a traditional panel IV estimation in which the dependent is transformed to keep the zero values in the estimation. In particular, we proceed to the IV estimation of the scaled variable $\ln \left(\varsigma+\frac{M_{i j t}}{M_{i i t}}\right)$ where $\varsigma$ is the minimal positive value of $\frac{M_{i j t}}{M_{i i t}}$ in our sample 8

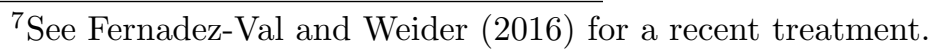

${ }^{8}$ See Cameron and Trivedi (2013) for a discussion of the optimal way of scaling a dependent variable to restore the zero values in the estimation sample.
} 
Table 4: IV estimations of attractiveness of migrant rights

\begin{tabular}{lccc}
\hline & PPML & Scaled OLS & Scaled IV \\
\hline lnGDPpcdiff & $3.193^{* * *}$ & $0.451^{* * *}$ & $0.556^{* * *}$ \\
& $(7.01)$ & $(2.73)$ & $(3.46)$ \\
lnPopD & 1.103 & $0.948^{*}$ & $1.795^{* * *}$ \\
& $(0.88)$ & $(1.87)$ & $(3.40)$ \\
lndistw & $-0.577^{* * *}$ & $-0.230^{* * *}$ & $-0.228^{* * *}$ \\
& $(-9.07)$ & $(-4.16)$ & $(-4.20)$ \\
commlangoff & $0.883^{* * *}$ & $0.703^{* * *}$ & $0.704^{* * *}$ \\
& $(9.15)$ & $(7.08)$ & $(9.32)$ \\
Schengenij2010 & $-0.244^{* *}$ & -0.003 & -0.001 \\
& $(-1.97)$ & $(-0.04)$ & $(0.01)$ \\
colony & $0.494^{* * *}$ & $0.754^{* * *}$ & $0.749^{* * *}$ \\
& $(4.14)$ & $(4.94)$ & $(5.00))$ \\
lnLij2001 & $0.172^{* * *}$ & $0.132^{* * *}$ & $0.132^{* * *}$ \\
& $(10.16)$ & $(13.68)$ & $(13.95)$ \\
lnLabMobl & $1.279^{* * *}$ & 0.096 & $1.582^{* * *}$ \\
& $(4.75)$ & $(0.71)$ & $(4.16)$ \\
\hline Observations & 26493 & 26493 & 26493 \\
Origin-time FE & YES & YES & YES \\
Destination FE & YES & YES & YES \\
F-stat first stage & - & - & $10785^{* * *}$ \\
$R^{2}$ & - & 0.667 & 0.666 \\
\hline
\end{tabular}

Notes: $t$ statistics in brackets; $* * *, * * *$ denote significance at the 1,5 and $10 \%$ level, respectively. Standard errors are clustered by countries of origin. Instrument used in column 3: share of the population of working age.

Table 4 reports the scaled IV estimations (see column 3). For comparison purposes, we also report the benchmark estimations using PPML (column 1) and those obtained using scaled OLS (column 2). The IV estimations support a positive and significant impact of rights concerning migrants' access to the labour market. This is in line with the positive impact obtained using the PPML estimator. The scaled OLS estimates produce an insignificant impact but are subject to two different biases. The first one is the bias due to the heteroskedastic nature of the data produced by the high proportion of zeros and the correlation between the covariates and the second moment of the error term (Santos Silva and Tenreyro, 2006). The second bias is due to the endogeneity of the migrants' rights. The comparison between the scaled OLS estimates in column 2 and the scaled IV ones (column 3) allows to grasp the size and the magnitude of this bias. The underestimation of the impact of migrant rights is consistent with a story in which an increase in the attractiveness 
of a destination leads to less generous labour market access for immigrants. All in all, the IV results suggest that the positive impact of rights facilitating labour market access for migrants is robust to the presence of endogenous policies.

\subsubsection{Placebo test}

A second source of endogeneity bias might arise if our variables of interest were subject to measurement error. To mitigate this concern, we conduct a placebo test using only a sample of countries belonging to the free mobility zone induced by the Schengen area. The rationale is the following. One of the important effects of the Schengen agreement is to facilitate the access of foreign workers to the labour market of countries belonging to that area. This takes at least two specific forms: (1) free mobility across countries with no or limited border control and (2) no requirement of getting a specific work permit in order to work in the destination country. This implies that the impact of the migrants' rights in the field of work should be neutralised. For other rights such as acquisition of nationality, Schengen does not play any role, however.

Table 5 reports the estimates of $\beta_{1}$ for the various categories of migrant rights for a sample of origin and destination countries that belong to the Schengen area. Interestingly, the results confirm that migrant rights concerning Labour Market Mobility are no longer significantly correlated with migration desires. In contrast, Access to Nationality is highly correlated with migration desires. As nationality might provide stronger political rights to foreign citizens, this positive and significant coefficient confirms the importance of migrants' rights in terms of the attractiveness of potential destinations. 
Table 5: Estimations within Schengen area only

\begin{tabular}{|c|c|c|c|c|c|c|}
\hline & M1 & M2 & M3 & M4 & M5 & M6 \\
\hline lnGDPpcdiff & $\begin{array}{c}3.911^{* * *} \\
(3.34)\end{array}$ & $\begin{array}{c}3.963^{* * *} \\
(3.25)\end{array}$ & $\begin{array}{c}3.808^{* * *} \\
(3.16)\end{array}$ & $\begin{array}{c}4.780^{* * *} \\
(3.32)\end{array}$ & $\begin{array}{c}4.000^{* * *} \\
(3.16)\end{array}$ & $\begin{array}{l}2.569^{*} \\
(1.80)\end{array}$ \\
\hline $\operatorname{lnPopD}$ & $\begin{array}{l}3.477 \\
(1.37)\end{array}$ & $\begin{array}{l}3.197 \\
(1.29)\end{array}$ & $\begin{array}{l}3.399 \\
(1.33)\end{array}$ & $\begin{array}{l}4.420 \\
(1.58)\end{array}$ & $\begin{array}{l}3.242 \\
(1.27)\end{array}$ & $\begin{array}{l}8.787 \\
(1.49)\end{array}$ \\
\hline lndistw & $\begin{array}{c}-0.658^{* * *} \\
(-3.10)\end{array}$ & $\begin{array}{c}-0.661^{* * *} \\
(-3.11)\end{array}$ & $\begin{array}{c}-0.664^{* * *} \\
(-3.16)\end{array}$ & $\begin{array}{c}-0.665^{* * *} \\
(-3.17)\end{array}$ & $\begin{array}{c}-0.661^{* * *} \\
(-3.11)\end{array}$ & $\begin{array}{c}-0.630^{* * *} \\
(-2.91)\end{array}$ \\
\hline commlangoff & $\begin{array}{l}-0.143 \\
(-0.66)\end{array}$ & $\begin{array}{l}-0.146 \\
(-0.67)\end{array}$ & $\begin{array}{l}-0.150 \\
(-0.70)\end{array}$ & $\begin{array}{l}-0.147 \\
(-0.68)\end{array}$ & $\begin{array}{l}-0.146 \\
(-0.67)\end{array}$ & $\begin{array}{l}-0.235 \\
(-1.09)\end{array}$ \\
\hline colony & $\begin{array}{l}0.183 \\
(1.11)\end{array}$ & $\begin{array}{l}0.185 \\
(1.12)\end{array}$ & $\begin{array}{l}0.181 \\
(1.11)\end{array}$ & $\begin{array}{l}0.183 \\
(1.11)\end{array}$ & $\begin{array}{l}0.185 \\
(1.12)\end{array}$ & $\begin{array}{l}0.185 \\
(1.05)\end{array}$ \\
\hline $\operatorname{lnLij} 2001$ & $\begin{array}{c}0.155^{* * *} \\
(5.56)\end{array}$ & $\begin{array}{c}0.155^{* * *} \\
(5.58)\end{array}$ & $\begin{array}{c}0.156^{* * *} \\
(5.61)\end{array}$ & $\begin{array}{c}0.155^{* * *} \\
(5.59)\end{array}$ & $\begin{array}{c}0.155^{* * *} \\
(5.54)\end{array}$ & $\begin{array}{c}0.156^{* * *} \\
(4.95)\end{array}$ \\
\hline lnLabMobl & $\begin{array}{l}0.369 \\
(0.88)\end{array}$ & & & & & \\
\hline lnFamReunl & & $\begin{array}{l}-0.026 \\
(-0.06)\end{array}$ & & & & \\
\hline lnPermResidl & & & $\begin{array}{l}1.630^{*} \\
(1.80)\end{array}$ & & & \\
\hline lnNationl & & & & $\begin{array}{c}0.687^{* * *} \\
(2.82)\end{array}$ & & \\
\hline lnPolPartl & & & & & $\begin{array}{l}0.067 \\
(0.27)\end{array}$ & \\
\hline $\operatorname{lnEducl}$ & & & & & & $\begin{array}{l}-1.525 \\
(-1.36) \\
\end{array}$ \\
\hline Observations & 2562 & 2562 & 2562 & 2562 & 2562 & 1872 \\
\hline
\end{tabular}

Notes: $t$ statistics in brackets; $* * *, * *,{ }^{*}$ denote significance at the 1,5 and $10 \%$ level, respectively. Standard errors are clustered by countries of origin.

\subsubsection{Different country samples}

The use of a different sample of destination countries aims to address two different considerations. The first one is related to the well-known issue of multilateral resistance to migration (Bertoli and Moraga, 2013) that can bias the estimates coming from a gravity model like ours 9 The second reason concerns the fact that some countries have implemented explicit integration policies much later and are less likely to be favoured destinations for aspiring

\footnotetext{
${ }^{9}$ The traditional solution to deal with the multilateral resistance to migration issue is to include origintime and destination-time $\mathrm{FE}$ in a regression like equation (1). This is not possible in our set-up given the focus on migrants' rights at destination. As a second best, we can check that our key estimates are robust to the change of the set of destinations for aspiring migrants.
} 
migrants. It is therefore important to see whether our estimates are not driven by countries that are quite different from the main destinations. We also conduct robustness checks excluding some origin countries in order to account for possible issues related to the incomplete coverage of the MIPEX indicators in terms of destination countries.

In Table 6 we exclude the United States, which is the main desired destination and accounts for almost $25 \%$ of expressed desired destinations. Similarly, we exclude the post2004 EU enlargement countries in Table 7 which have a rather different institutional history (i.e. they are mainly former communist countries) and tend to be less attractive. The results remain quantitatively and qualitatively very robust. In Table 8, we exclude the origin countries for which the main destination country is not covered in MIPEX. Though the coefficient is quite similar to the benchmark result, Permanent Residence is no longer significant whereas for the other indicators results remain robust 10 Table 9 shows that estimations limited to the subsample of countries for which MIPEX data is available as of 2007 also yield very robust results.

\footnotetext{
${ }^{10}$ We also run the regressions on countries for which the share of destinations for which MIPEX data is available is below $50 \%$. Results are very robust to the benchmark estimations and can be obtained upon request.
} 
Table 6: Estimation results excluding the US as destination

\begin{tabular}{|c|c|c|c|c|c|c|}
\hline & M1 & M2 & M3 & M4 & M5 & M6 \\
\hline $\operatorname{lnGDPpcdiff}$ & $\begin{array}{c}2.824^{* * *} \\
(6.48)\end{array}$ & $\begin{array}{c}2.940^{* * *} \\
(6.76)\end{array}$ & $\begin{array}{c}2.918^{* * *} \\
(6.65)\end{array}$ & $\begin{array}{c}3.111^{* * *} \\
(6.29)\end{array}$ & $\begin{array}{c}2.887^{* * *} \\
(6.62)\end{array}$ & $\begin{array}{c}3.208^{* * *} \\
(5.23)\end{array}$ \\
\hline $\operatorname{lnPopD}$ & $\begin{array}{l}1.366 \\
(1.11)\end{array}$ & $\begin{array}{l}0.605 \\
(0.48)\end{array}$ & $\begin{array}{l}0.647 \\
(0.53)\end{array}$ & $\begin{array}{l}1.286 \\
(1.06)\end{array}$ & $\begin{array}{l}0.501 \\
(0.42)\end{array}$ & $\begin{array}{l}0.894 \\
(0.47)\end{array}$ \\
\hline lndistw & $\begin{array}{c}-0.470^{* * *} \\
(-5.42)\end{array}$ & $\begin{array}{c}-0.472^{* * *} \\
(-5.44)\end{array}$ & $\begin{array}{c}-0.472^{* * *} \\
(-5.43)\end{array}$ & $\begin{array}{c}-0.472^{* * *} \\
(-5.45)\end{array}$ & $\begin{array}{c}-0.472^{* * *} \\
(-5.45)\end{array}$ & $\begin{array}{c}-0.463^{* * *} \\
(-5.31)\end{array}$ \\
\hline commlangoff & $\begin{array}{c}0.991^{* * *} \\
(6.89)\end{array}$ & $\begin{array}{c}0.993^{* * *} \\
(6.87)\end{array}$ & $\begin{array}{c}0.991^{* * *} \\
(6.87)\end{array}$ & $\begin{array}{c}0.992^{* * *} \\
(6.86)\end{array}$ & $\begin{array}{c}0.993^{* * *} \\
(6.87)\end{array}$ & $\begin{array}{c}0.985^{* * *} \\
(6.99)\end{array}$ \\
\hline Schengenij2010 & $\begin{array}{c}-0.446^{* * *} \\
(-3.27)\end{array}$ & $\begin{array}{c}-0.451^{* * *} \\
(-3.31)\end{array}$ & $\begin{array}{c}-0.446^{* * *} \\
(-3.26)\end{array}$ & $\begin{array}{c}-0.450^{* * *} \\
(-3.30)\end{array}$ & $\begin{array}{c}-0.452^{* * *} \\
(-3.32)\end{array}$ & $\begin{array}{c}-0.441^{* * *} \\
(-3.28)\end{array}$ \\
\hline colony & $\begin{array}{c}0.504^{* * *} \\
(3.27)\end{array}$ & $\begin{array}{c}0.506^{* * *} \\
(3.27)\end{array}$ & $\begin{array}{c}0.504^{* * *} \\
(3.26)\end{array}$ & $\begin{array}{c}0.505^{* * *} \\
(3.26)\end{array}$ & $\begin{array}{c}0.506^{* * *} \\
(3.27)\end{array}$ & $\begin{array}{c}0.522^{* * *} \\
(3.66)\end{array}$ \\
\hline $\operatorname{lnLij} 2001$ & $\begin{array}{c}0.166^{* * *} \\
(9.87)\end{array}$ & $\begin{array}{c}0.166^{* * *} \\
(9.84)\end{array}$ & $\begin{array}{c}0.166^{* * *} \\
(9.86)\end{array}$ & $\begin{array}{c}0.166^{* * *} \\
(9.87)\end{array}$ & $\begin{array}{c}0.166^{* * *} \\
(9.84)\end{array}$ & $\begin{array}{c}0.165^{* * *} \\
(9.86)\end{array}$ \\
\hline lnLabMobl & $\begin{array}{c}1.137^{* * *} \\
(4.04)\end{array}$ & & & & & \\
\hline lnFamReunl & & $\begin{array}{l}0.143 \\
(0.60)\end{array}$ & & & & \\
\hline lnPermResidl & & & $\begin{array}{l}0.721^{*} \\
(1.71)\end{array}$ & & & \\
\hline $\operatorname{lnNationl}$ & & & & $\begin{array}{c}0.612^{* * *} \\
(4.82)\end{array}$ & & \\
\hline lnPolPartl & & & & & $\begin{array}{l}0.031 \\
(0.26)\end{array}$ & \\
\hline $\operatorname{lnEducl}$ & & & & & & $\begin{array}{l}0.535^{*} \\
(1.66)\end{array}$ \\
\hline Observations & 25942 & 25942 & 25942 & 25942 & 25942 & 19567 \\
\hline
\end{tabular}

Notes: $t$ statistics in brackets; ${ }^{* * *},{ }^{* *},{ }^{*}$ denote significance at the 1,5 and $10 \%$ level, respectively. Standard errors are clustered by countries of origin. 
Table 7: Estimations excluding Eastern European countries as destinations

\begin{tabular}{|c|c|c|c|c|c|c|}
\hline & M1 & M2 & M3 & M4 & M5 & M6 \\
\hline $\operatorname{lnGDPpcdiff}$ & $\begin{array}{c}3.331^{* * *} \\
(7.01)\end{array}$ & $\begin{array}{c}3.462^{* * *} \\
(7.35)\end{array}$ & $\begin{array}{c}3.437^{* * *} \\
(7.18)\end{array}$ & $\begin{array}{c}3.768^{* * *} \\
(6.92)\end{array}$ & $\begin{array}{c}3.534^{* * *} \\
(6.72)\end{array}$ & $\begin{array}{c}3.794^{* * *} \\
(5.45)\end{array}$ \\
\hline $\operatorname{lnPopD}$ & $\begin{array}{l}0.771 \\
(0.59)\end{array}$ & $\begin{array}{l}-0.072 \\
(-0.05)\end{array}$ & $\begin{array}{l}-0.053 \\
(-0.04)\end{array}$ & $\begin{array}{c}0.616 \\
(0.47)\end{array}$ & $\begin{array}{l}-0.191 \\
(-0.15)\end{array}$ & $\begin{array}{l}0.231 \\
(0.11)\end{array}$ \\
\hline lndistw & $\begin{array}{c}-0.574^{* * *} \\
(-8.79)\end{array}$ & $\begin{array}{c}-0.576^{* * *} \\
(-8.84)\end{array}$ & $\begin{array}{c}-0.576^{* * *} \\
(-8.80)\end{array}$ & $\begin{array}{c}-0.575^{* * *} \\
(-8.85)\end{array}$ & $\begin{array}{c}-0.576^{* * *} \\
(-8.84)\end{array}$ & $\begin{array}{c}-0.575^{* * *} \\
(-8.93)\end{array}$ \\
\hline commlangoff & $\begin{array}{c}0.880^{* * *} \\
(8.98)\end{array}$ & $\begin{array}{c}0.884^{* * *} \\
(8.95)\end{array}$ & $\begin{array}{c}0.881^{* * *} \\
(8.93)\end{array}$ & $\begin{array}{c}0.884^{* * *} \\
(8.99)\end{array}$ & $\begin{array}{c}0.885^{* * *} \\
(8.98)\end{array}$ & $\begin{array}{c}0.853^{* * *} \\
(9.34)\end{array}$ \\
\hline Schengenij2010 & $\begin{array}{c}-0.228^{*} \\
(-1.81)\end{array}$ & $\begin{array}{l}-0.234^{*} \\
(-1.86)\end{array}$ & $\begin{array}{c}-0.230^{*} \\
(-1.82)\end{array}$ & $\begin{array}{l}-0.232^{*} \\
(-1.85)\end{array}$ & $\begin{array}{c}-0.237^{*} \\
(-1.88)\end{array}$ & $\begin{array}{l}-0.172 \\
(-1.34)\end{array}$ \\
\hline colony & $\begin{array}{c}0.500^{* * *} \\
(4.14)\end{array}$ & $\begin{array}{c}0.502^{* * *} \\
(4.14)\end{array}$ & $\begin{array}{c}0.500^{* * *} \\
(4.12)\end{array}$ & $\begin{array}{c}0.500^{* * *} \\
(4.12)\end{array}$ & $\begin{array}{c}0.501^{* * *} \\
(4.14)\end{array}$ & $\begin{array}{c}0.506^{* * *} \\
(4.68)\end{array}$ \\
\hline $\operatorname{lnLij} 2001$ & $\begin{array}{c}0.168^{* * *} \\
(9.87)\end{array}$ & $\begin{array}{c}0.168^{* * *} \\
(9.85)\end{array}$ & $\begin{array}{c}0.168^{* * *} \\
(9.87)\end{array}$ & $\begin{array}{c}0.168^{* * *} \\
(9.89)\end{array}$ & $\begin{array}{c}0.168^{* * *} \\
(9.85)\end{array}$ & $\begin{array}{c}0.169^{* * *} \\
(9.94)\end{array}$ \\
\hline lnLabMobl & $\begin{array}{c}1.286^{* * *} \\
(4.69)\end{array}$ & & & & & \\
\hline lnFamReunl & & $\begin{array}{l}0.160 \\
(0.69)\end{array}$ & & & & \\
\hline lnPermResidl & & & $\begin{array}{l}0.782^{*} \\
(1.87)\end{array}$ & & & \\
\hline lnNationl & & & & $\begin{array}{c}0.815^{* * *} \\
(6.07)\end{array}$ & & \\
\hline lnPolPartl & & & & & $\begin{array}{l}0.617^{*} \\
(1.73)\end{array}$ & \\
\hline $\operatorname{lnEducl}$ & & & & & & $\begin{array}{l}0.441 \\
(1.30)\end{array}$ \\
\hline Observations & 17424 & 17424 & 17424 & 17424 & 17424 & 13327 \\
\hline
\end{tabular}

Notes: $t$ statistics in brackets; ${ }^{* * *},{ }^{* *},{ }^{*}$ denote significance at the 1,5 and $10 \%$ level, respectively. Standard errors are clustered by countries of origin. 
Table 8: Estimations excluding origin countries without a MIPEX country as main destination

\begin{tabular}{|c|c|c|c|c|c|c|}
\hline & M1 & M2 & M3 & M4 & M5 & M6 \\
\hline lnGDPpcdiff & $\begin{array}{c}3.267^{* * *} \\
(6.26)\end{array}$ & $\begin{array}{c}3.392^{* * *} \\
(6.57)\end{array}$ & $\begin{array}{c}3.375^{* * *} \\
(6.43)\end{array}$ & $\begin{array}{c}3.572^{* * *} \\
(6.12)\end{array}$ & $\begin{array}{c}3.357^{* * *} \\
(6.38)\end{array}$ & $\begin{array}{c}3.814^{* * *} \\
(5.04)\end{array}$ \\
\hline $\ln$ PopD & $\begin{array}{l}1.065 \\
(0.77)\end{array}$ & $\begin{array}{l}0.257 \\
(0.18)\end{array}$ & $\begin{array}{l}0.298 \\
(0.21)\end{array}$ & $\begin{array}{l}0.948 \\
(0.68)\end{array}$ & $\begin{array}{l}0.168 \\
(0.12)\end{array}$ & $\begin{array}{l}0.532 \\
(0.25)\end{array}$ \\
\hline lndistw & $\begin{array}{c}-0.583^{* * *} \\
(-8.78)\end{array}$ & $\begin{array}{c}-0.586^{* * *} \\
(-8.84)\end{array}$ & $\begin{array}{c}-0.585^{* * *} \\
(-8.80)\end{array}$ & $\begin{array}{c}-0.585^{* * *} \\
(-8.84)\end{array}$ & $\begin{array}{c}-0.586^{* * *} \\
(-8.84)\end{array}$ & $\begin{array}{c}-0.584^{* * *} \\
(-9.01)\end{array}$ \\
\hline commlangoff & $\begin{array}{c}0.850^{* * *} \\
(8.29)\end{array}$ & $\begin{array}{c}0.853^{* * *} \\
(8.25)\end{array}$ & $\begin{array}{c}0.850^{* * *} \\
(8.24)\end{array}$ & $\begin{array}{c}0.852^{* * *} \\
(8.28)\end{array}$ & $\begin{array}{c}0.853^{* * *} \\
(8.29)\end{array}$ & $\begin{array}{c}0.817^{* * *} \\
(8.59)\end{array}$ \\
\hline Schengenij2010 & $\begin{array}{c}-0.262^{* *} \\
(-2.05)\end{array}$ & $\begin{array}{c}-0.269^{* *} \\
(-2.10)\end{array}$ & $\begin{array}{c}-0.264^{* *} \\
(-2.06)\end{array}$ & $\begin{array}{c}-0.266^{* *} \\
(-2.08)\end{array}$ & $\begin{array}{c}-0.270^{* *} \\
(-2.11)\end{array}$ & $\begin{array}{l}-0.204 \\
(-1.57)\end{array}$ \\
\hline colony & $\begin{array}{c}0.548^{* * *} \\
(4.28)\end{array}$ & $\begin{array}{c}0.550^{* * *} \\
(4.28)\end{array}$ & $\begin{array}{c}0.549^{* * *} \\
(4.27)\end{array}$ & $\begin{array}{c}0.549^{* * *} \\
(4.27)\end{array}$ & $\begin{array}{c}0.550^{* * *} \\
(4.29)\end{array}$ & $\begin{array}{c}0.573^{* * *} \\
(5.03)\end{array}$ \\
\hline $\operatorname{lnLij} 2001$ & $\begin{array}{c}0.169^{* * *} \\
(9.39)\end{array}$ & $\begin{array}{c}0.169^{* * *} \\
(9.36)\end{array}$ & $\begin{array}{c}0.169^{* * *} \\
(9.38)\end{array}$ & $\begin{array}{c}0.169^{* * *} \\
(9.39)\end{array}$ & $\begin{array}{c}0.169^{* * *} \\
(9.37)\end{array}$ & $\begin{array}{c}0.168^{* * *} \\
(9.53)\end{array}$ \\
\hline lnLabMobl & $\begin{array}{c}1.268^{* * *} \\
(4.29)\end{array}$ & & & & & \\
\hline lnFamReunl & & $\begin{array}{l}0.113 \\
(0.44)\end{array}$ & & & & \\
\hline lnPermResidl & & & $\begin{array}{l}0.688 \\
(1.47)\end{array}$ & & & \\
\hline lnNationl & & & & $\begin{array}{c}0.653^{* * *} \\
(4.75)\end{array}$ & & \\
\hline lnPolPartl & & & & & $\begin{array}{l}0.040 \\
(0.29)\end{array}$ & \\
\hline $\operatorname{lnEducl}$ & & & & & & $\begin{array}{l}0.433 \\
(1.14)\end{array}$ \\
\hline Observations & 21254 & 21254 & 21254 & 21254 & 21254 & 16167 \\
\hline
\end{tabular}

Notes: $t$ statistics in brackets; ${ }^{* * *},{ }^{* *},{ }^{*}$ denote significance at the 1,5 and $10 \%$ level, respectively. Standard errors are clustered by countries of origin. 
Table 9: Estimations keeping only countries in MIPEX as of 2007

\begin{tabular}{|c|c|c|c|c|c|c|}
\hline & M1 & M2 & M3 & M4 & M5 & M6 \\
\hline lnGDPpcdiff & $\begin{array}{c}2.674^{* * *} \\
(5.64)\end{array}$ & $\begin{array}{c}2.826^{* * *} \\
(6.06)\end{array}$ & $\begin{array}{c}2.819^{* * *} \\
(5.92)\end{array}$ & $\begin{array}{c}3.037^{* * *} \\
(5.55)\end{array}$ & $\begin{array}{c}2.764^{* * *} \\
(5.84)\end{array}$ & $\begin{array}{c}2.474^{* * *} \\
(3.43)\end{array}$ \\
\hline $\operatorname{lnPopD}$ & $\begin{array}{l}1.957 \\
(1.60)\end{array}$ & $\begin{array}{l}1.090 \\
(0.84)\end{array}$ & $\begin{array}{l}1.127 \\
(0.93)\end{array}$ & $\begin{array}{l}1.993^{*} \\
(1.65)\end{array}$ & $\begin{array}{l}0.955 \\
(0.81)\end{array}$ & $\begin{array}{l}3.462 \\
(1.52)\end{array}$ \\
\hline lndistw & $\begin{array}{c}-0.479^{* * *} \\
(-4.72)\end{array}$ & $\begin{array}{c}-0.480^{* * *} \\
(-4.74)\end{array}$ & $\begin{array}{c}-0.481^{* * *} \\
(-4.73)\end{array}$ & $\begin{array}{c}-0.481^{* * *} \\
(-4.75)\end{array}$ & $\begin{array}{l}-0.480^{* * *} \\
(-4.73))\end{array}$ & $\begin{array}{c}-0.470^{* * *} \\
(-4.59)\end{array}$ \\
\hline commlangoff & $\begin{array}{c}0.999^{* * *} \\
(5.98)\end{array}$ & $\begin{array}{c}1.000^{* * *} \\
(5.95)\end{array}$ & $\begin{array}{c}0.998^{* * *} \\
(5.96)\end{array}$ & $\begin{array}{c}0.997^{* * *} \\
(5.93)\end{array}$ & $\begin{array}{c}1.000^{* * *} \\
(5.94)\end{array}$ & $\begin{array}{c}0.992^{* * *} \\
(6.24)\end{array}$ \\
\hline Schengenij2010 & $\begin{array}{c}-0.424^{* *} \\
(-2.47)\end{array}$ & $\begin{array}{c}-0.430^{* *} \\
(-2.51)\end{array}$ & $\begin{array}{c}-0.423^{* *} \\
(-2.45)\end{array}$ & $\begin{array}{c}-0.427^{* *} \\
(-2.50)\end{array}$ & $\begin{array}{c}-0.431^{* *} \\
(-2.52)\end{array}$ & $\begin{array}{c}-0.406^{* *} \\
(-2.38)\end{array}$ \\
\hline colony & $\begin{array}{c}0.593^{* * *} \\
(3.29)\end{array}$ & $\begin{array}{c}0.595^{* * *} \\
(3.28)\end{array}$ & $\begin{array}{c}0.592^{* * *} \\
(3.27)\end{array}$ & $\begin{array}{c}0.595^{* * *} \\
(3.27)\end{array}$ & $\begin{array}{c}0.595^{* * *} \\
(3.28)\end{array}$ & $\begin{array}{c}0.660^{* * *} \\
(4.02)\end{array}$ \\
\hline $\operatorname{lnLij2001}$ & $\begin{array}{c}0.145^{* * *} \\
(8.08)\end{array}$ & $\begin{array}{c}0.145^{* * *} \\
(8.05)\end{array}$ & $\begin{array}{c}0.145^{* * *} \\
(8.08)\end{array}$ & $\begin{array}{c}0.145^{* * *} \\
(8.08)\end{array}$ & $\begin{array}{c}0.145^{* * *} \\
(8.05)\end{array}$ & $\begin{array}{c}0.136^{* * *} \\
(7.96)\end{array}$ \\
\hline lnLabMobl & $\begin{array}{c}1.229^{* * *} \\
(4.15)\end{array}$ & & & & & \\
\hline lnFamReunl & & $\begin{array}{l}0.127 \\
(0.50)\end{array}$ & & & & \\
\hline lnPermResidl & & & $\begin{array}{l}0.849^{*} \\
(1.86)\end{array}$ & & & \\
\hline lnNationl & & & & $\begin{array}{c}0.651^{* * *} \\
(4.62)\end{array}$ & & \\
\hline lnPolPartl & & & & & $\begin{array}{l}0.018 \\
(0.13)\end{array}$ & \\
\hline $\operatorname{lnEducl}$ & & & & & & $\begin{array}{l}0.419 \\
(1.21) \\
\end{array}$ \\
\hline Observations & 20792 & 20792 & 20792 & 20792 & 20792 & 14417 \\
\hline
\end{tabular}

Notes: $t$ statistics in brackets; $* * * * * *$ denote significance at the 1,5 and $10 \%$ level, respectively. Standard errors are clustered by countries of origin.

\subsection{Dyadic fixed effects}

In this section, we run a set of estimations including origin-time and dyadic FE. Hence, compared to the benchmark equation (1), equation (4) no longer includes destination FE and time-invariant dyadic control variables. One advantage of this specification is that dyadic FE $\left(\gamma_{i j}\right)$ will better capture the effect of dyadic time-invariant factors, compared to a limited set of observable variables. It therefore minimises the risk of omitted variables, a third potential source of endogeneity bias. A drawback is that this estimation is computationally more demanding and that the estimation program needs to drop some observations to achieve 
convergence. The estimated equation takes the following form:

$\ln \left(\frac{M_{i j t}}{M_{i i t}}\right)=\alpha+\gamma_{i t}+\gamma_{i j}+\beta_{1} \ln \left(M I P E X_{j t-1}\right)+\beta_{2} \ln \left(\right.$ PoP $\left._{j t}\right)+\beta_{3} \ln \left(G D P p c d i f f_{i j t}\right)+\epsilon_{i j t}$.

Identification now relies on the within-dyad variation. Although this fixed-effects structure is quite demanding, Table 10 confirms our main result: more extensive migrants' rights tend to be correlated with higher migration desires. Labour Market Mobility remains the indicator with the highest coefficient, whereas that of Education becomes positive and significant.11

Table 10: Estimations with dyadic and origin-time FE

\begin{tabular}{|c|c|c|c|c|c|c|}
\hline & M1 & M2 & M3 & M4 & M5 & M6 \\
\hline lnGDPpcdiff & $\begin{array}{c}2.435^{* * *} \\
(5.82)\end{array}$ & $\begin{array}{c}2.591^{* * *} \\
(6.26)\end{array}$ & $\begin{array}{c}2.518^{* * *} \\
(5.98)\end{array}$ & $\begin{array}{c}2.680^{* * *} \\
(5.78)\end{array}$ & $\begin{array}{c}2.506^{* * *} \\
(5.95)\end{array}$ & $\begin{array}{c}2.848^{* * *} \\
(4.33)\end{array}$ \\
\hline $\ln$ PopD & $\begin{array}{c}1.941^{* *} \\
(2.38)\end{array}$ & $\begin{array}{l}1.464^{*} \\
(1.78)\end{array}$ & $\begin{array}{l}1.344^{*} \\
(1.66)\end{array}$ & $\begin{array}{c}1.899^{* *} \\
(2.31)\end{array}$ & $\begin{array}{l}1.213 \\
(1.49)\end{array}$ & $\begin{array}{c}3.463^{* * *} \\
(2.59)\end{array}$ \\
\hline $\operatorname{lnLij} 2001$ & $\begin{array}{c}2.779^{* * *} \\
(2.93)\end{array}$ & $\begin{array}{c}2.320^{* *} \\
(2.42)\end{array}$ & $\begin{array}{c}2.042^{* *} \\
(2.19)\end{array}$ & $\begin{array}{c}2.716^{* * *} \\
(2.85)\end{array}$ & $\begin{array}{c}1.909^{* *} \\
(2.04)\end{array}$ & $\begin{array}{c}4.522^{* * *} \\
(3.07)\end{array}$ \\
\hline lnLabMobl & $\begin{array}{c}0.875^{* * *} \\
(4.72)\end{array}$ & & & & & \\
\hline lnFamReunl & & $\begin{array}{c}0.308^{* *} \\
(2.37)\end{array}$ & & & & \\
\hline lnPermResidl & & & $\begin{array}{l}0.467^{*} \\
(1.72)\end{array}$ & & & \\
\hline lnNationl & & & & $\begin{array}{c}0.493^{* * *} \\
(4.25)\end{array}$ & & \\
\hline lnPolPartl & & & & & $\begin{array}{l}0.018 \\
(0.15)\end{array}$ & \\
\hline $\operatorname{lnEducl}$ & & & & & & $\begin{array}{c}0.633^{* * *} \\
(3.34)\end{array}$ \\
\hline Observations & 15198 & 15198 & 15198 & 15198 & 15198 & 10996 \\
\hline
\end{tabular}

Notes: $t$ statistics in brackets; $* * *, * * *$ denote significance at the 1,5 and $10 \%$ level, respectively. Standard errors are clustered by countries of origin.

\footnotetext{
${ }^{11}$ We ran the benchmark estimation (i.e. with origin-time and destination FE) on the same subsample as the one used with the dyadic structure. The results (available upon request) remain highly consistent with the benchmark estimations. Hence, we can exclude that results are driven by a sample composition effect. The dyadic FE rather allow to capture dimensions not accounted for in the benchmark regressions.
} 


\subsection{Changing the dependent variable}

The dependent variable used in equation $(1), \frac{M_{i j t}}{M_{i i t}}$, is derived from traditional micro-founded RUM models of migration. In fact, this ratio corresponds exactly to the term prescribed by the theoretical model. Alternatively, given the fixed effects structure of our model, we can replace our dependent variable by its numerator, i.e. the number of respondents that state a desire to emigrate from country $i$ to country $j$ at time $t\left(M_{i j t}\right)$ (see also Beine et al., 2015, Ortega and Peri, 2013). In that case, the role of aspiring stayers $\left(M_{i i t}\right)$ is captured by the origin-time $\mathrm{FE}\left(\gamma_{i t}\right)$. The estimated equation becomes:

$$
\begin{aligned}
\ln \left(M_{i j t}\right) & =\alpha+\gamma_{i t}+\gamma_{j}+\beta_{1} \ln \left(\text { MIPEX }_{j t-1}\right)+\beta_{2} \ln \left(\text { PoP }_{j t}\right) \\
& +\beta_{3} \ln \left(\text { GDPpcdiff }_{i j t}\right)+\beta_{4} \ln \left(\text { Netw }_{i j 2001}\right)+\sum_{z} \beta_{z} \text { controls }_{i j}+\epsilon_{i j t} .
\end{aligned}
$$

Table 11 shows that results are qualitatively unaffected: Labour Market Mobility, Permanent Residence and Access to Nationality are positively correlated with migration desires. Moreover, the size of the coefficients is only marginally affected. 
Table 11: Estimations with dependent $M_{i j}$

\begin{tabular}{|c|c|c|c|c|c|c|}
\hline & M1 & M2 & M3 & M4 & M5 & M6 \\
\hline $\operatorname{lnGDPpcdiff}$ & $\begin{array}{c}2.648^{* * *} \\
(6.30)\end{array}$ & $\begin{array}{c}2.769^{* * *} \\
(6.49)\end{array}$ & $\begin{array}{c}2.733^{* * *} \\
(6.42)\end{array}$ & $\begin{array}{c}2.892^{* * *} \\
(6.24)\end{array}$ & $\begin{array}{c}2.706^{* * *} \\
(6.37)\end{array}$ & $\begin{array}{c}3.035^{* * *} \\
(4.68)\end{array}$ \\
\hline $\operatorname{lnPopD}$ & $\begin{array}{l}1.081 \\
(0.77)\end{array}$ & $\begin{array}{l}0.448 \\
(0.31)\end{array}$ & $\begin{array}{l}0.468 \\
(0.34)\end{array}$ & $\begin{array}{l}0.986 \\
(0.73)\end{array}$ & $\begin{array}{l}0.293 \\
(0.21)\end{array}$ & $\begin{array}{l}-0.370 \\
(-0.19)\end{array}$ \\
\hline lndistw & $\begin{array}{c}-0.568^{* * *} \\
(-9.13)\end{array}$ & $\begin{array}{c}-0.570^{* * *} \\
(-9.17)\end{array}$ & $\begin{array}{c}-0.570^{* * *} \\
(-9.15)\end{array}$ & $\begin{array}{c}-0.569^{* * *} \\
(-9.18)\end{array}$ & $\begin{array}{c}-0.570^{* * *} \\
(-9.19)\end{array}$ & $\begin{array}{c}-0.570^{* * *} \\
(-9.18)\end{array}$ \\
\hline commlangoff & $\begin{array}{c}0.889^{* * *} \\
(9.78)\end{array}$ & $\begin{array}{c}0.891^{* * *} \\
(9.77)\end{array}$ & $\begin{array}{c}0.889^{* * *} \\
(9.75)\end{array}$ & $\begin{array}{c}0.891^{* * *} \\
(9.77)\end{array}$ & $\begin{array}{c}0.891^{* * *} \\
(9.78)\end{array}$ & $\begin{array}{c}0.867^{* * *} \\
(10.07)\end{array}$ \\
\hline Schengenij2010 & $\begin{array}{c}-0.215^{*} \\
(-1.75)\end{array}$ & $\begin{array}{c}-0.219^{*} \\
(-1.78)\end{array}$ & $\begin{array}{c}-0.215^{*} \\
(-1.75)\end{array}$ & $\begin{array}{c}-0.218^{*} \\
(-1.78)\end{array}$ & $\begin{array}{c}-0.220^{*} \\
(-1.79)\end{array}$ & $\begin{array}{l}-0.178 \\
(-1.41)\end{array}$ \\
\hline colony & $\begin{array}{c}0.524^{* * *} \\
(4.73)\end{array}$ & $\begin{array}{c}0.527^{* * *} \\
(4.75)\end{array}$ & $\begin{array}{c}0.524^{* * *} \\
(4.73)\end{array}$ & $\begin{array}{c}0.527^{* * *} \\
(4.74)\end{array}$ & $\begin{array}{c}0.527^{* * *} \\
(4.75)\end{array}$ & $\begin{array}{c}0.508^{* * *} \\
(4.96)\end{array}$ \\
\hline $\operatorname{lnLij} 2001$ & $\begin{array}{c}0.164^{* * *} \\
(10.73)\end{array}$ & $\begin{array}{c}0.164^{* * *} \\
(10.73)\end{array}$ & $\begin{array}{c}0.164^{* * *} \\
(10.73)\end{array}$ & $\begin{array}{c}0.164^{* * *} \\
(10.74)\end{array}$ & $\begin{array}{c}0.164^{* * *} \\
(10.73)\end{array}$ & $\begin{array}{c}0.165^{* * *} \\
(10.93)\end{array}$ \\
\hline lnLabMobl & $\begin{array}{c}1.058^{* * *} \\
(4.60)\end{array}$ & & & & & \\
\hline lnFamReunl & & $\begin{array}{l}0.223 \\
(1.07)\end{array}$ & & & & \\
\hline lnPermResidl & & & $\begin{array}{c}0.808^{* *} \\
(2.32)\end{array}$ & & & \\
\hline lnNationl & & & & $\begin{array}{c}0.573^{* * *} \\
(4.37)\end{array}$ & & \\
\hline lnPolPartl & & & & & $\begin{array}{l}0.029 \\
(0.27)\end{array}$ & \\
\hline $\operatorname{lnEducl}$ & & & & & & $\begin{array}{l}0.424 \\
(1.29)\end{array}$ \\
\hline Observations & 26493 & 26493 & 26493 & 26493 & 26493 & 20118 \\
\hline
\end{tabular}

Notes: $t$ statistics in brackets; ${ }^{* * *},{ }^{* *},{ }^{*}$ denote significance at the 1,5 and $10 \%$ level, respectively. Standard errors are clustered by countries of origin.

\subsection{Heterogenous response across categories of respondents}

The rich structure of the data provided by the Gallup World poll surveys allows to investigate whether there is heterogeneity in the way aspiring migrants with different characteristics account for specific migrant rights in forming their optimal choice of location. For each set of regressions, we recalculate the dependent variable defined in equation (1) on the subsample of individuals with some particular characteristics.

Table 12 shows results for highly skilled individuals (i.e. with at least some tertiary education), by family structure (in partnership or with children) and by gender (men versus 
women). Labour Market Mobility is highly significant in all cases. Its coefficient is higher than in the benchmark estimations for high skilled workers (1.62>1.28) and it is also higher for men than for women $(1.40>1.17)$. Permanent Residence, although in general weakly significant, is more significant for high skilled individuals than in the benchmark estimations. The indicator loses significance in some samples. Access to Nationality is consistently significant in all the estimations but the coefficient is higher for men than for women $(0.8>0.6)$.

The importance of the different dimensions of migrant rights can also be analysed for individuals in different age groups. Table 13 reveals that the Labour Market Mobility and Access to Nationality indicators are highly significant with similar coefficients across all age groups. As in previous estimations, Permanent Residence loses significance in some cases. Interestingly, Education access for immigrant youth is positively and significantly correlated with higher migration desires for individuals aged 15 to 24 years, who can personally benefit from educational opportunities at destination.

Table 12: Estimations on different subsamples of individuals

\begin{tabular}{lcccccc}
\hline & Bench-all & HS only & Partner & Child & Men & Women \\
\hline lnLabMobl & $1.279^{* * *}$ & $1.620^{* * *}$ & $1.291^{* * *}$ & $1.349^{* * *}$ & $1.399^{* * *}$ & $1.166^{* * *}$ \\
& $(4.75)$ & $(5.54)$ & $(4.22)$ & $(4.78)$ & $(4.81)$ & $(4.03)$ \\
lnFamReunl & 0.167 & 0.276 & 0.022 & 0.071 & 0.106 & 0.218 \\
& $(0.72)$ & $(1.34)$ & $(0.08)$ & $(0.24)$ & $(0.47)$ & $(0.84)$ \\
lnPermResidl & $0.736^{*}$ & $0.880^{* *}$ & 0.719 & 0.585 & 0.658 & $0.784^{*}$ \\
& $(1.78)$ & $(2.26)$ & $(1.56)$ & $(1.24)$ & $(1.57)$ & $(1.78)$ \\
lnNationl & $0.695^{* * *}$ & $0.754^{* * *}$ & $0.793^{* * *}$ & $0.710^{* * *}$ & $0.797^{* * *}$ & $0.604^{* * *}$ \\
& $(5.70)$ & $(5.14)$ & $(5.65)$ & $(5.00)$ & $(5.26)$ & $(4.94)$ \\
lnPolPartl & 0.045 & 0.159 & -0.020 & 0.110 & 0.049 & -0.010 \\
& $(0.37)$ & $(1.30)$ & $(-0.14)$ & $(0.68)$ & $(0.39)$ & $(-0.07)$ \\
Observations & 26493 & 25801 & 26351 & 26493 & 26399 & 26465 \\
\hline lnEducl & 0.399 & 0.404 & 0.197 & 0.559 & 0.399 & 0.411 \\
& $(1.19)$ & $(1.41)$ & $(0.50)$ & $(1.57)$ & $(1.20)$ & $(1.15)$ \\
Observations & 20118 & 20010 & 19976 & 20118 & 20080 & 20118 \\
\hline
\end{tabular}

Notes: $t$ statistics in brackets; ${ }^{* * *},{ }^{* *},{ }^{*}$ denote significance at the 1,5 and $10 \%$ level, respectively. Standard errors are clustered by countries of origin. 
Table 13: Estimations by age structure

\begin{tabular}{lccccc}
\hline & Benchmark & $15-24$ & $25+$ & $29+$ & $25-64$ \\
\hline lnLabMobl & $1.279^{* * *}$ & $1.299^{* * *}$ & $1.321^{* * *}$ & $1.312^{* * *}$ & $1.348^{* * *}$ \\
& $(4.75)$ & $(4.15)$ & $(4.52)$ & $(4.53)$ & $(4.86)$ \\
lnFamReunl & 0.167 & 0.301 & 0.078 & 0.124 & 0.004 \\
& $(0.72)$ & $(0.94)$ & $(0.34)$ & $(0.49)$ & $(0.02)$ \\
lnPermResidl & $0.736^{*}$ & 0.947 & $0.725^{*}$ & $0.838^{*}$ & 0.673 \\
& $(1.78)$ & $(1.55)$ & $(1.80)$ & $(1.92)$ & $(1.59)$ \\
lnNationl & $0.695^{* * *}$ & $0.760^{* * *}$ & $0.712^{* * *}$ & $0.708^{* * *}$ & $0.696^{* * *}$ \\
& $(5.70)$ & $(4.49)$ & $(5.54)$ & $(5.21)$ & $(5.05)$ \\
lnPolPartl & 0.045 & 0.024 & 0.059 & 0.107 & 0.015 \\
& $(0.37)$ & $(0.10)$ & $(0.50)$ & $(0.89)$ & $(0.13)$ \\
Observations & 26493 & 25689 & 26493 & 26465 & 26465 \\
\hline lnEducl & 0.399 & $0.856^{* *}$ & 0.322 & 0.423 & 0.378 \\
& $(1.19)$ & $(2.15)$ & $(0.86)$ & $(1.08)$ & $(1.02)$ \\
Observations & 20118 & 19568 & 20118 & 20118 & 20118 \\
\hline
\end{tabular}

Notes: $t$ statistics in brackets; ${ }^{* * *}, * * *$ denote significance at the 1,5 and $10 \%$ level, respectively. Standard errors are clustered by countries of origin.

\section{Conclusion}

In this paper, we analyse the effect of migrant rights on the destination choice of potential migrants by combining data on migration desires from the Gallup World Poll surveys and migrant rights from MIPEX. The advantage of focusing on desired rather than on observed flows lies in the unconstrained nature of the choice set of potential desired destinations. A respondent desiring to move abroad can state any country as preferred destination without any limitation, even if he does not have the means to actually move. Moreover, observed migratory movements are strongly affected by restrictions induced by immigration policies, for which consistent and complete data is still missing.

We empirically estimate the choice of aspiring immigrants among the 38 alternative destinations for which we have MIPEX data during the period 2007-2014. Controlling for traditional determinants of migration such as economic prospects, distance, networks and common historical links, our evidence indicates that immigrants tend to favour countries with more generous regulations for labour market entry, for permanent residence as well as easier access to the nationality of the host country. These results are robust to the presence of an endogenous labour market access. They are also robust across different specifications 
and different subsamples. The positive and highly significant coefficients are preserved when altering the choice set by dropping the United States or the new member states of the European Union. The results remain valid when we keep in the sample only origin countries for which the main destination is also available in MIPEX or when we focus only on countries

for which data is available over the entire period 2007-2014. The importance of migrant rights is also maintained when we use different estimation strategies, such as a dyadic FE structure.

Interestingly, the data allow to account for a heterogeneous impact of the various MIPEX indicators on migration desires by re-estimating our benchmark model on various subsamples of respondents, i.e. for low versus high skilled, men versus women, working age versus young, respondents with or without children and respondents with or without a partner. We find that labour market mobility seems to be slightly more important for men than for women, although it also remains the most significant and important indicator for women. Migrant rights linked to education are particularly important for individuals aged 15 to 24 years, who might benefit from educational opportunities at destination.

Our results suggest that migrant rights significantly affect the attractiveness of destination countries for desiring migrants. This result holds even though we control for traditional socio-economic determinants of migration flows. The role of migrant rights, taken in a very broad sense, in the management of migration flows should therefore not be underestimated.

\section{References}

Ariu, A., Docquier, F., and Squicciarini, M. P. (2016). Governance quality and net migration flows. Regional Science and Urban Economics, 60:238-248.

Ashby, N. J. (2010). Freedom and international migration. Southern Economic Journal, $77(1): 49-62$.

Baudassé, T., Bazillier, R., and Issifou, I. (2018). Migration and institutions: Exit and voice (from abroad)? Journal of Economic Surveys, 32(3):727-766.

Bazillier, R. and Moullan, Y. (2010). Employment protection and migration. DR LEO 2010-09, Laboratoire d'économie d'Orléans.

Bazillier, R. and Moullan, Y. (2012). Does employment protection influence migration flows towards OECD countries? Revue économique, 63(3):491-499. 
Beine, M., Bertoli, S., and Fernández-Huertas Moraga, J. (2016). A practitioners guide to gravity models of international migration. The World Economy, 39(4):496-512.

Beine, M., Docquier, F., and Özden, Ç. (2011). Diasporas. Journal of Development Economics, 95(1):30-41.

Beine, M., Docquier, F., and Özden, Ç. (2015). Dissecting Network Externalities in International Migration. JODE - Journal of Demographic Economics, 81(4):379-408.

Beine, M. and Parsons, C. (2015). Climatic factors as determinants of international migration. The Scandinavian Journal of Economics, 117(2):723-767.

Bergh, A., Mirkina, I., and Nilsson, T. (2015). Pushed by poverty or by institutions? Determinants of global migration flows. Working Paper Series 1077, Research Institute of Industrial Economics.

Bertoli, S. and Moraga, J. F.-H. (2013). Multilateral resistance to migration. Journal of Development Economics, 102:79-100.

Bertoli, S. and Ruyssen, I. (2018). Networks and migrants' intended destination. Journal of Economic Geography, 18(4):705-728.

Cameron, A. and Trivedi, P. (2013). Regression Analysis of Count Data. Cambridge University Press: New York, NY.

Cattaneo, C. and Peri, G. (2016). The migration response to increasing temperatures. Journal of Development Economics, 122:127-146.

Cigagna, C. and Sulis, G. (2015). On the potential interaction between labour market institutions and immigration policies. International Journal of Manpower, 36(4):441-468.

Dao, T. H., Docquier, F., Parsons, C., and Peri, G. (2018). Migration and development: Dissecting the anatomy of the mobility transition. Journal of Development Economics, 132:88-101.

De Giorgi, G. and Pellizzari, M. (2009). Welfare migration in Europe. Labour Economics, 16(4):353-363. 
Delogu, M., Docquier, F., and Machado, J. (2018). Globalizing labor and the world economy: the role of human capital. Journal of Economic Growth, 23(2):223-258.

Docquier, F. and Machado, J. (2016). Global Competition for Attracting Talents and the World Economy. The World Economy, 39(4):530-542.

Docquier, F., Machado, J., and Sekkat, K. (2015). Efficiency gains from liberalizing labor mobility. The Scandinavian Journal of Economics, 117(2):303-346.

Docquier, F., Peri, G., and Ruyssen, I. (2014). The cross-country determinants of potential and actual migration. International Migration Review, 48:S37-S99.

Dustmann, C. and Okatenko, A. (2014). Out-migration, wealth constraints, and the quality of local amenities. Journal of Development Economics, 110:52-63.

Esipova, N., Pugliese, A., and Ray, J. (2011). Gallup world poll: The many faces of global migration. IOM Migration Research Series, 43.

Fernadez-Val, I. and Weider, M. (2016). Individual and time effects in nonlinear panel models with large n, t. Journal of Econometrics, 192:291-312.

Gallup (2018). Gallup country data set details 20082013, available online at http://www.gallup.com/services/177797/country-data-set-details.aspx. Technical report.

Geis, W., Uebelmesser, S., and Werding, M. (2013). How do migrants choose their destination country? An analysis of institutional determinants. Review of International Economics, 21(5):825-840.

Giulietti, C. (2014). Is the minimum wage a pull factor for immigrants? ILR Review, 67(3):649-674.

Grogger, J. and Hanson, G. H. (2011). Income maximization and the selection and sorting of international migrants. Journal of Development Economics, 95(1):42-57.

Gubert, F. and Senne, J.-N. (2016). Is the European Union attractive for potential migrants?: An investigation of migration intentions across the world. OECD Social, Employment and Migration Working Papers No 188, OECD Publishing, Paris. 
Hatton, T. J. (2014). The economics of international migration: A short history of the debate. Labour Economics, 30:43-50.

Kaufmann, D., Kraay, A., and Mastruzzi, M. (2009). Governance matters VIII : aggregate and individual governance indicators 1996-2008. Policy Research Working Paper Series 4978, The World Bank.

Manchin, M. and Orazbayev, S. (2018). Social networks and the intention to migrate. World Development, 109(C):360-374.

Mayer, T. and Zignago, S. (2011). Notes on CEPIIs distances measures: The GeoDist database. Working Papers 2011-25, CEPII research center.

Migali, S. (2018). Migration and institutions: Evidence from internal EU mobility. The World Economy, 41(1):29-58.

Nejad, M. N. and Young, A. T. (2016). Want freedom, will travel: Emigrant self-selection according to institutional quality. European Journal of Political Economy, 45:71-84.

Ortega, F. and Peri, G. (2013). The effect of income and immigration policies on international migration. Migration Studies, 1(1):47-74.

Pedersen, P. J., Pytlikova, M., and Smith, N. (2008). Selection and network effects - Migration flows into OECD countries 1990-2000. European Economic Review, 52(7):1160-1186.

Ruyssen, I. and Salomone, S. (2018). Female migration: A way out of discrimination? Journal of Development Economics, 130:224-241.

Santos Silva, J. and Tenreyro, S. (2006). The log of gravity. The Review of Economics and statistics, 88(4):641-658.

Tenreyro, S. (2007). On the trade impact of nominal exchange rate volatility. Journal of Development Economics, 82(2):485-508.

Windmeijer, F. and Santos Silva, J. (1997). Endogeneity in count data models: an application to demand in health care. Journal of Applied Econometrics, 12(3):281-294. 


\section{Appendices}

\section{A Additional information on data}

Table A.1: GWP ranking of countries in MIPEX

\begin{tabular}{lc}
\hline Destination & GWP ranking \\
\hline United States & 1 \\
France & 2 \\
United Kingdom & 3 \\
Germany & 4 \\
Canada & 5 \\
Spain & 6 \\
Australia & 7 \\
Italy & 8 \\
Switzerland & 13 \\
Sweden & 14 \\
Japan & 15 \\
Netherlands & 19 \\
Turkey & 20 \\
Austria & 21 \\
Norway & 22 \\
Belgium & 23 \\
New Zealand & 24 \\
Greece & 27 \\
Denmark & 29 \\
Korea & 34 \\
Finland & 42 \\
Ireland & 43 \\
Portugal & 44 \\
Czech Republic & 62 \\
Poland & 66 \\
Cyprus & 70 \\
Luxembourg & 76 \\
Romania & 84 \\
Bulgaria & 88 \\
Croatia & 90 celand \\
Slovenia & 102 \\
Hungary & 106 \\
Malta & 109 \\
Estonia & 122 \\
Lithuania & 141 \\
Slovakia & 149 \\
Latvia & 158 \\
\hline Note: & 163 \\
\hline
\end{tabular}

Notes: The table illustrates how the countries appearing in the MIPEX database rank according to the number of times they have been mentioned as preferred destination by respondents expressing a desire to migrate in the Gallup World Polls. 
Table A.2: Main GWP destination countries unavailable in MIPEX

\begin{tabular}{lc}
\hline Destination & GWP Ranking \\
\hline Saudi Arabia & 9 \\
Russia & 10 \\
South Africa & 11 \\
United Arab Emirates & 12 \\
Brazil & 16 \\
Argentina & 17 \\
China & 18 \\
Egypt & 25 \\
Nigeria & 26 \\
Mexico & 28 \\
Qatar & 30 \\
Ivory Coast & 31 \\
Costa Rica & 32 \\
Kuwait & 33 \\
Ghana & 35 \\
India & 36 \\
Singapore & 37 \\
Morocco & 38 \\
Malaysia & 39 \\
Chile & 40 \\
\hline
\end{tabular}

Notes: The table illustrates the most popular GWP destinations (i.e. countries most frequently mentioned as preferred destination by respondents expressing a desire to migrate) that do not appear in the MIPEX database. 


\section{B Contemporaneous Indicators}

Note that the sample period is 2008-2014, whereas the benchmark version (with lagged MIPEX indicators) allows to include Gallup data for the year 2015.

Table B.3: Estimations with contemporaneous $M I P E X_{t}$

\begin{tabular}{|c|c|c|c|c|c|c|}
\hline & M1 & M2 & M3 & M4 & M5 & M6 \\
\hline lnGDPpcdiff & $\begin{array}{c}2.896^{* * *} \\
(5.85)\end{array}$ & $\begin{array}{c}3.044^{* * *} \\
(6.34)\end{array}$ & $\begin{array}{c}3.023^{* * *} \\
(6.17)\end{array}$ & $\begin{array}{c}3.114^{* * *} \\
(6.18)\end{array}$ & $\begin{array}{c}3.014^{* * *} \\
(6.20)\end{array}$ & $\begin{array}{c}2.993^{* * *} \\
(5.56)\end{array}$ \\
\hline $\operatorname{lnPopD}$ & $\begin{array}{l}1.522 \\
(1.34)\end{array}$ & $\begin{array}{l}1.019 \\
(0.96)\end{array}$ & $\begin{array}{l}1.023 \\
(0.96)\end{array}$ & $\begin{array}{l}1.207 \\
(1.11)\end{array}$ & $\begin{array}{l}0.869 \\
(0.82)\end{array}$ & $\begin{array}{c}3.555^{* *} \\
(2.49)\end{array}$ \\
\hline lndistw & $\begin{array}{c}-0.513^{* * *} \\
(-7.93)\end{array}$ & $\begin{array}{c}-0.514^{* * *} \\
(-7.96)\end{array}$ & $\begin{array}{c}-0.514^{* * *} \\
(-7.95)\end{array}$ & $\begin{array}{c}-0.513^{* * *} \\
(-7.94)\end{array}$ & $\begin{array}{c}-0.514^{* * *} \\
(-7.95)\end{array}$ & $\begin{array}{c}-0.521^{* * *} \\
(-8.16)\end{array}$ \\
\hline commlangoff & $\begin{array}{c}0.890^{* * *} \\
(9.83)\end{array}$ & $\begin{array}{c}0.890^{* * *} \\
(9.80)\end{array}$ & $\begin{array}{c}0.889^{* * *} \\
(9.81)\end{array}$ & $\begin{array}{c}0.891^{* * *} \\
(9.84)\end{array}$ & $\begin{array}{c}0.891^{* * *} \\
(9.84)\end{array}$ & $\begin{array}{c}0.876^{* * *} \\
(10.25)\end{array}$ \\
\hline Schengenij2010 & $\begin{array}{l}-0.087 \\
(-0.69)\end{array}$ & $\begin{array}{l}-0.087 \\
(-0.69)\end{array}$ & $\begin{array}{l}-0.087 \\
(-0.69)\end{array}$ & $\begin{array}{l}-0.086 \\
(-0.69)\end{array}$ & $\begin{array}{l}-0.087 \\
(-0.70)\end{array}$ & $\begin{array}{l}-0.071 \\
(-0.55)\end{array}$ \\
\hline colony & $\begin{array}{c}0.492^{* * *} \\
(4.59)\end{array}$ & $\begin{array}{c}0.492^{* * *} \\
(4.58)\end{array}$ & $\begin{array}{c}0.492^{* * *} \\
(4.58)\end{array}$ & $\begin{array}{c}0.491^{* * *} \\
(4.57)\end{array}$ & $\begin{array}{c}0.492^{* * *} \\
(4.58)\end{array}$ & $\begin{array}{c}0.507^{* * *} \\
(5.12)\end{array}$ \\
\hline $\operatorname{lnLij} 2001$ & $\begin{array}{c}0.184^{* * *} \\
(11.32)\end{array}$ & $\begin{array}{c}0.184^{* * *} \\
(11.31)\end{array}$ & $\begin{array}{c}0.184^{* * *} \\
(11.32)\end{array}$ & $\begin{array}{c}0.184^{* * *} \\
(11.32)\end{array}$ & $\begin{array}{c}0.184^{* * *} \\
(11.31)\end{array}$ & $\begin{array}{c}0.179^{* * *} \\
(10.94)\end{array}$ \\
\hline $\operatorname{lnLabMob}$ & $\begin{array}{c}0.573^{* *} \\
(2.34)\end{array}$ & & & & & \\
\hline lnFamReun & & $\begin{array}{l}0.225 \\
(1.32)\end{array}$ & & & & \\
\hline lnPermResid & & & $\begin{array}{l}0.537^{*} \\
(1.79)\end{array}$ & & & \\
\hline lnNation & & & & $\begin{array}{c}0.312^{* * *} \\
(2.77)\end{array}$ & & \\
\hline lnPolPart & & & & & $\begin{array}{l}0.056 \\
(0.54)\end{array}$ & \\
\hline $\operatorname{lnEduc}$ & & & & & & $\begin{array}{c}0.146 \\
(0.62)\end{array}$ \\
\hline Observations & 28233 & 28233 & 28233 & 28233 & 28233 & 22446 \\
\hline
\end{tabular}

Notes: $t$ statistics in brackets; $* * *, * *, *$ denote significance at the 1,5 and $10 \%$ level, respectively. Standard errors are clustered by countries of origin. 